

\section{Daftar Isi (Table of Content) Journal of Government
Civil Society}

\begin{tabular}{|c|c|}
\hline \multirow{3}{*}{$145-158$} & $\begin{array}{l}\text { Political Law's Reconstruction of Village Apparatus to Realize Independent } \\
\text { Village in Indonesia }\end{array}$ \\
\hline & Hartati' ${ }^{1}$ Pahrudin HM$^{2}$, Elita Rahmi ${ }^{1}$ \\
\hline & $\begin{array}{l}\text { ('Faculty of Law, Universitas Jambi, Indonesia) } \\
\text { ('Departement of Government Science, STISIP Nurdin Hamzah Jambi, Indonesia) }\end{array}$ \\
\hline \multirow{3}{*}{$159-179$} & $\begin{array}{l}\text { Policy of a Merit System to Make a Good and Clean Government in The } \\
\text { Middle of Bureaucratic Politicization }\end{array}$ \\
\hline & $\begin{array}{l}\text { Yahya Pandega Putra1, 2, Eko Priyo Purnomo, }{ }^{1,} \text {, Suswanta Suswanta1, } \\
\text { Aulia Nur Kasiwi1, }\end{array}$ \\
\hline & $\begin{array}{l}\text { ('Jusuf Kalla School of Government, Universitas Muhammadiyah Yogyakarta, Indonesia) } \\
\text { ('Department of Government Affairs and Administration, Universitas Muhammadiyah } \\
\text { Yogyakarta, Indonesia) }\end{array}$ \\
\hline \multirow{3}{*}{$181-199$} & $\begin{array}{l}\text { Smart Human Security: Economic Safety for Micro, Small and Medium } \\
\text { Enterprises (MSMEs) to Face The Impact of The Covid-19 Global Pandemic }\end{array}$ \\
\hline & Elyta $^{1}$, Warjio ${ }^{2}$, Ahmad Azrin Bin Adnan ${ }^{3}$ \\
\hline & $\begin{array}{l}\text { ('Faculty of Social and Political Sciences, Universitas Tanjungpura, Indonesia) } \\
\text { ('Faculty of Social and Political Sciences, Universitas Sumatera Utara, Indonesia) } \\
\text { ( }{ }^{3} \text { Faculty of Business and Management, Universiti Sultan Zainal Abidin (UnisZa), } \\
\text { Trengganu, Malaysia) }\end{array}$ \\
\hline \multirow{3}{*}{$201-218$} & $\begin{array}{l}\text { Using The "Return on Investment" Strategy to Sustain Logistic Supply } \\
\text { Provider Toward Indonesia's Logistic Policy }\end{array}$ \\
\hline & Riska Rahayu ${ }^{1,2}$, Eko Priyo Purnomo, ${ }^{1}$, Ajree Ducol Malawani ${ }^{1,3}$ \\
\hline & $\begin{array}{l}\text { ('Jusuf Kalla School of Government, Universitas Muhammadiyah Yogyakarta, Indonesia) } \\
\text { ('Magister of Government and Public Affairs, Universitas Muhammadiyah Yogyakarta, } \\
\text { Indonesia) } \\
\text { ('Doctoral Program of Political Islam, Universitas Muhammadiyah Yogyakarta, Indonesia) }\end{array}$ \\
\hline \multirow{3}{*}{$219-228$} & $\begin{array}{l}\text { Indonesia Universal Health Coverage Implementation on University } \\
\text { Students }\end{array}$ \\
\hline & Adityo Pratikno Ramadhan ${ }^{1}$, Budiyono Budiyono ${ }^{1}$, Djonet Santoso ${ }^{1}$ \\
\hline & ('Sustainable Development Goals Center, Universitas Bengkulu, Indonesia) \\
\hline
\end{tabular}


The Local Government of Kulon Progo Regency Innovation in Subduing Capitalism through Community Empowerment

229 - 247 Muhammad Eko Atmojo ${ }^{1}$, Helen Dian Fridayani ${ }^{2}$

('Departement of Government Science, Universitas Muhammadiyah Yogyakarta, Indonesia)

('Departement of Political Science, National Cheng Kung University, Taiwan)

Land Administration Policy In Bantul and Sleman Districts

$249-272$

Subekti Widiyasno1, Dyah Mutiarin 1, Herdin Arie Saputra1, Ikhwan

Rahmatika Latif ${ }^{1}$

('Department of Government Affairs and Administration, Universitas Muhammadiyah Yogyakarta, Indonesia)

Increasing Local Own-Source Revenue through The Development of The Regional Tourism Sector

$273-291$

Harries Madiistriyatno', Ida Musdafia Ibrahim², Dudung Hadiwijaya ${ }^{3}$

('Program Studi Magister Manajemen Sekolah Tinggi Manajemen IMMI, Indonesia) (2Program Studi Manajemen Sekolah Tinggi Ilmu Ekonomi Y.A.I, Indonesia)

(3Program Studi Manajemen, Universitas Muhammadiyah Tangerang, Indonesia) 


\title{
Political Law's Reconstruction of Village Apparatus to Realize Independent Village in Indonesia
}

\author{
Hartati ${ }^{1}$, Pahrudin $\mathrm{HM}^{2 *}$, Elita Rahmi ${ }^{1}$ \\ ${ }^{1}$ Faculty of Law, Universitas Jambi, Indonesia \\ ${ }^{2}$ Departement of Government Science, STISIP Nurdin Hamzah Jambi, Indonesia \\ *Email Correspondence: pahrudinhm9@gmail.com
}

\begin{abstract}
Indonesian Village Law 2014 states that the purpose of village regulation is to create an independent village. Village management in Indonesia is carried out using a self-governing community system that requires apparatus that has good capacity. On the other hand, the existence of village apparatus in Indonesia still does not have the capacity needed to organize the government to become an independent village. Therefore, it is necessary to do a political law reconstruction to find a solution to the inequality of expectations of village regulation and the reality of the quality of village officials like this. Political law functions as a bridge to the goals to be achieved and is strongly influenced by the social reality of society. This research was conducted using a qualitative approach with the type of library research by reviewing data related to villages in Indonesia, especially village government. The results of this study revealed that only $7.43 \%$ were independent villages, most of village apparatuses unprofessional, poverty rate $9.66 \%$, and unemployment rate of $5.01 \%$. This requires a solution through a series of solution policies so that the objectives of village regulation towards independent villages can be achieved so that the prosperous community can be achieved.
\end{abstract}

Keywords: Village, independent, political-law, apparatus

\begin{abstract}
ABSTRAK
Undang-Undang Desa Tahun 2014 menyebutkan bahwa tujuan peraturan desa adalah untuk mewujudkan desa yang mandiri. Pengelolaan desa di Indonesia dilakukan dengan sistem kemasyarakatan swakelola yang membutuhkan aparatur yang memiliki kapasitas yang baik. Di sisi lain, keberadaan perangkat desa di Indonesia masih belum memiliki kapasitas yang dibutuhkan untuk menyelenggarakan pemerintahan menjadi desa yang mandiri. Oleh karena itu, perlu dilakukan rekonstruksi politik hukum untuk mencari solusi atas ketimpangan ekspektasi peraturan desa dan realitas kualitas aparatur desa seperti ini. Hukum politik berfungsi sebagai jembatan menuju tujuan yang ingin dicapai dan sangat dipengaruhi oleh realitas sosial masyarakat. Penelitian ini dilakukan dengan menggunakan pendekatan kualitatif dengan jenis studi pustaka dengan mengkaji data-data terkait desa di Indonesia khususnya pemerintahan desa. Hasil penelitian menunjukkan bahwa desa mandiri hanya 7,43\%, perangkat desa sebagian besar tidak profesional, tingkat kemiskinan 9,66\%, dan tingkat pengangguran 5,01\%. Untuk itu diperlukan solusi melalui serangkaian kebijakan solusi agar tujuan peraturan desa menuju desa mandiri dapat tercapai sehingga masyarakat sejahtera dapat tercapai.
\end{abstract}

Kata Kunci: Desa, independen, hukum politik, aparat

Citation : Hartati, Pahrudin H, and Elita Rahmi. 2020. "Political Law's Reconstruction of Village Apparatus to Realize Independent Village in Indonesia." Journal of Government and Civil Society 4(2):145158. 


\section{INTRODUCTION}

Discussing the independent village is always interesting to do because of the various characteristics inherent in the region which is the largest part of Indonesia. Administratively, the Indonesia village is the smallest region that has the government equipment recognized in the political system adopted by Indonesia. In addition, according to data Central Statistics Agency [BPS] (2018), the village is also home to the majority of Indonesia's population and is home to most of the country's natural resources.

The various characteristics above make the village always a concern of the government which is manifested in the birth of various laws and regulations, both in the Old Order, the New Order, even in the Reform era. The Old Order government paid attention to the village through Law Number 22 Year 1948 and Law Number 1 Year 1957 concerning the Principles of Regional Government, Law Number 18 Year 1965 concerning the Principles of Regional Government, Law Number 19 Year 1965 concerning 'Desapraja' as a Transitional Form to Accelerate the Realization of Level III Regions in the Entire Territory of the Republic of Indonesia. Meanwhile, the New Order gave rise to Law Number 5 Year 1974 concerning the Principles of Regional Government and Law Number 5 of 1979 concerning Village Government. After the reformation, the regulations governing the village emerged in various forms, both specifically regulating the village as well as being part of a law. This phenomenon can be seen in Law Number 22 Year 1999 and Law Number 32 Year 2004 concerning Regional Government, and Law Number 6 Year 2014 concerning Villages as the latest regulation.

These regulations were raised as a form of government attention to the village, while also intended to address the problems that arose in them, especially Law Number 6 Year 2014. This latest village regulation manifests itself in the form of self-governing community and local self-government in the form of delegation of authority covering the affairs of the affairs of village administration, implementation of village development, community development, and empowerment of rural communities (Brezovšek, 2014). According to Huda (2015), village regulation in the form of various regulations is aimed at addressing issues surrounding the position of indigenous peoples, democratization, diversity, community participation, progress and equitable development, poverty and socio-cultural conditions that can disrupt the integrity of the nation.

Administratively, Indonesian Law Village Number 6 Year 2014 is indeed better than previous similar regulations. It's just that, attention to the village should not only stop the birth of regulations like this, but the implications in the future must also be considered. The objective of the village regulation closely related to the quality of human resources which are the motor of village management, especially related to village officials. Human resources are acute problems of the village because their quality is still low, not only related to the community in general, but also village officials or village government (Asrori, 
2014). The study by Syaifullah (2017), Anto and Amir (2017), Sahi (2018) and Nugroho etc. (2018) also revealed that quality the village apparatus is still not optimal or is still very necessary for improved and the ability, willingness and potential of the village apparatus as well impacts and approaches to governance and implementation development has not been maximized because human resources are still limited. This phenomenon is of course closely related to other problems inherent in the domicile of the largest part of the Indonesian people, namely poverty, unemployment, low education and health (Maschab, 2013).

On this basis, there needs to be an effort to overcome the problem of limited human resources in the village to achieve the objectives of village regulation as contained in Law Number 6 Year 2014 about Village. Based on the legal perspective, the effort is manifested in legal politics which is interpreted as an official line of law that will be applied, both by making new laws and by replacing old laws, in order to achieve state goals (Mahfud MD, 2009). In the same context it is said that the selection of certain legal politics as a bridge to the ideals of a country is strongly influenced by dynamic social realities in society and international legal political conditions (Hartono, 1991). Therefore it is said that legal politics is not as understood so far as the formation of law through legislation, but strengthening the capacity and quality of law enforcement and the means of law enforcement and the development of legal culture are also part of it (Rosadi and Desmon, 2012). While from a political perspective, this effort is an implementation of the concept of public policy. As it is known that as a party constitutionally handed over by the state management task, the government is required to be able to present a variety of development policies that can overcome problems faced by the community. This is in line with the statement of Professor Michael Porter, who stated that the effectiveness of the management of the state carried out by a government is very dependent on the policy that it occupies (Nugroho, 2017). That is, the role of the government is very necessary in an effort to release the people from the confines of the problems they face in this life. In relation to the above, there are various kinds of understanding of public policy which were raised by several parties. Thomas $\mathrm{R}$. Dye (1990) who is considered one of the scholars of policy studies, for example, said that public policy is what the government does or does not do to overcome the problems faced by its people. Meanwhile, Steven A. Peterson (in Nugroho 1, 2017) interpreted public policy simply by taking it as an action taken by the government to overcome various problems. Policies are essentially decisions that directly regulate the management and distribution of natural, financial, and human resources in the public interest (Suharto, 2010). Public policy refers to a term or concept to explain certain specific action options that are very specific, such as in certain fields in public facilities sectors. 
Related to this, there needs to be reconstruction related to the existence of Law Number 6 Year 2014 about Village, which regulates the objectives of a very good village arrangement, but on the other hand human resources are still very limited. Through legal politics, the gap between the expectations (goals) of village regulation and the minimum quality of village resources can be minimized. This is in line with Nonet and Selznick (1978) which states that society must play an active role in resolving the problems it faces because justice is not achieved through miracles, but requires qualified figures in a variety of ways they can do it. This effort also seems to be in line with Fadli et al. (2012) who stated that village management must pay attention to how the village apparatus adapted to the capacity needed to manage this important area in the modern world.

The purpose of this study is to analyze the legal politics of village governance and to find alternative solutions to the problems of village human resources that are still limited in an effort to realize independent villages.

\section{RESEARCH METHODS}

This study uses a qualitative research approach to determine the political law of village governance and apparatus in an effort to realize an Indonesian independent village. Qualitative research method provide opportunities for researchers to be able to do a detailed description and interpretation in order to gain a holistic understanding (Marvasti, 2004). The type of research is library research by reviewing data related to village government law politics in Indonesia. Data collection was carried out through village data survey activities in Indonesia, village human resource data and the results of studies related to village governance in Indonesia. After the data is collected, the data analysis is done qualitatively: reducing data, displaying data, and conclusion (Miles and Huberman, 1992).

\section{RESULTS AND DISCUSSION}

As is known that after The 1998 Reformation, there have been many changes in Indonesia's political and developmental order. One of the important aspects produced is related to the village. Before reform, the village was more positioned as an object of development, however, after that this lowest administrative area was independently subject to development. The goal is to reduce the gap rural and urban development that tends to be urban bias. In addition, bringing government services closer to the level village, so that it becomes a solution for the socio-economic change of the village. Village as the subject of development, it is expected to be able to bring service closer towards citizens through infrastructure development and empowerment. Starting from moving the economy, building educational facilities, health, energy facilities, infrastructure, transportation, and communication, as well as other facilities needed. In accordance with the mandate of Law Number 6 Year 2014, villages need to be protected and empowered 
to be strong, advanced, independent. Village independent ones can create a solid foundation in carrying out governance and development towards a just, prosperous society and prosperous.

As an effort to build villages in Indonesia to be better and contribute to people's lives, The Government divided villages into several categories, namely Independent Village, Developed Village, Advanced Village, Developed Village, Disadvantaged villages and Very Disadvantaged Villages. According to the Minister of Village Regulation No. 2 Year 2016, Independent Village, or it could be called Sembada Village is anAdvanced Village that has the ability to carry out village development to improve the quality of life and life as much as the welfare of the Village community with social security, economic resilience and ecological resilience sustainable. Advanced Village, or can be referred to as PreSembada Village, is a village that has the potential of social, economic and ecological resources, as well as the ability to manage it to improve the welfare of the village community, the quality of human life, and overcome poverty.Developed Village, or as Mad Village, is a potential village to become Advanced Village, which has the potential of social, economic and ecological resources but has not managed it optimally to improve the welfare of the village community, the quality of human life and tackle poverty.Disadvantaged villages, or can be referred to as Pre-Mad Village, are villages that have potential social, economic and ecological resources but have not, or lacked management in an effort to improve the welfare of the village community, the quality of human life and experience poverty in various forms.Very Disadvantaged, or can be called Primary Village, is a village that experiences vulnerability due to natural disasters, economic shocks, and social conflicts so that it is not capable of managing potential social, economic and ecological resources, and experiencing poverty in various forms.

The problem is how the method can be used to position each village in Indonesia in that particular category. One of the methods commonly used by the government to rank villages in Indonesia is to use Village Development Index (IPD) concept. This is done because the level of progress and development of village development needs to be measured uses several sizes that are functionally interrelated for describe the concept comprehensively. Several dimensions compiled to include at the same time several variables and indicators. Delivery dimensions are expected to be complementary to describe the level of development progress in each village. IPD is based on Law Number 6 of 2014 concerning Villages, especially on Article 74 concerning Village Development Needs and Article 78 concerning Village Development Goals. Article 74 states that there are at least 4 aspects that are necessary fulfilled in village development namely: (1) Basic Needs; (2) Basic Services; (3) Environment; and (4) Empowerment Activities Villagers. In the explanation section of the Act, needs the basis is defined as an effort to meet the needs of food, clothing and shelter. Meanwhile, basic services include education, health, and basic 
infrastructure. Whereas in article 78 the purpose of village development include: (1) Community Welfare; (2) Quality of Life; and (3) Poverty Reduction. This is realized through (1) Needs Basic; (2) Facilities; (3) Infrastructure; (4) Local Economic Development; and (5) Sustainable Use of Natural Resources. The results of the synthesis contained in the regulation are then realized in 5 main dimensions which become a reference in categorizing villages in Indonesia. This is the 5 dimensions that become a measure of the ranking of villages in Indonesia using the IPD indicator.

Until now, measuring village development in Indonesia using the IPD indicator has been carried out twice, in 2015 for the planning phase and in 2018 for the evaluation phase (BPS, 2018). Based on BPS data (2018), throughout Indonesia there are 75.436 villages with various categories. The diversity of these village categories is based on IPD level which is based on five dimensions, namely Basic Service Dimensions, Infrastructure Condition Dimensions, Transportation Dimensions, Public Service Dimensions, and Village Government Implementation Dimensions. As a result, the existence of villages in Indonesia emerged in three categories, namely villages with underdeveloped status as many as 14.461 villages $(19,17 \%)$, developing villages as many as 55.369 villages $(73,40 \%)$, and independent villages with 5.606 villages (7,43\%). Based on data in 2018, all dimensions of IPD increased when compared to 2014, the highest increase $(9,81$ points) existed in the Implementation of Village Government dimensions, while the smallest increase occurred in the Basic Services dimension (0,92 points).

Meanwhile, other data that is also closely related to the village is the problem of poverty and unemployment. Based on BPS data (September 2018), Indonesia's poverty rate is still in the range of $9.66 \%$ (25.67 million people) where as many as 15.54 million of these are domiciled in the village. The unemployment rate in Indonesia based on BPS data (2018) is also still quite large $(5.01 \%)$, most of which are people living in rural areas.

In addition to the three problems above, another problem that is also inherent in the village is related to the quality of the village apparatus which is still far from the required standard. This is as raised in studies conducted by Syaifullah (2017), Anto and Amir (2017), Sahi (2018) and Nugroho etc. (2018) which states that the quality of village apparatus is still low. This finding is in line with Suwardjo (2009) summary which mentions that there are various problems faced village government in carrying out its duties, namely: limitations of staff or employees both in quality and quality quantity that affects the implementation of government village; quality and quantity of assistance, training and monitoring village development is low so that it affects the effectiveness and efficiency of program interventions; village isolation which results in lack of accessibility community towards public service centers; low welfare of the village related to provision basic services and village economic development; the quality and competence of village human resources is still low and limited; the position of the dominant local figure is still 
a reference in policy making both cultural and formal causing the role of the village government system to be dominated the spirit of feudalism and clientelism.

Based on the data above, villages that are home to the majority of the population of this country still face various problems. From the government side, it can be said that only a small proportion of villages $(7,43 \%)$ in Indonesia have achieved the main objectives of their regulation, namely the realization of independent villages. Not to mention if it is associated with the problem of poverty, unemployment which is still closely attached to the villagers and village apparatus quality is still low.

Regulatory, efforts to overcome these village problems have been carried out by the government, both through village law and related ministerial policies. Law No. 4 of 2016 is the main legal basis for village management and is a reference for other village-related policies. Technical management of village management is included in Minister of Village, Regional Development Disadvantaged, and Transmigration of the Republic of Indonesia Number 2 Year 2016 Article 1 Paragraph 11 Regarding the Village Build Index mentions that the independent village, or can be called the Sembada village is advanced villages that have the ability to carry out development village to increase the quality of life and life as much as possible welfare of village communities with social security, economic resilience, and sustainable ecological resilience. A village, can be said to be an independent village if it has ownership three indices in it are the index of social security, resilience economy and ecological resilience.

The main point of this minister regulation requires the availability of quality village officials. This is important because the village apparatus is the backbone of village management with a line of capital that it has. There are several areas of authority, according to Article 18 of Law No.6/2014, which was given to villages, namely: organizing village government; implementation of village development; village community development; and empowering village communities. Then the authority of the village, based on Article 19 of Law No.6/2014 includes four things, namely: authority based on origin rights; village scale local authority; authority assigned by the Government, Regional Government Province, or Regency/City Government; other authorities assigned by the Government, Government Provincial Region, or Regency/City Government in accordance with the provisions of the legislation. Furthermore, in carrying out the authority is based on community initiative, origin rights, and customs. With the issuance of the law provides space for village government and community in the village to regulate and manage the potential of villages more broadly to achieve his vision. This can be seen in Article 20 and Article 21 that the implementation the authority is regulated and administered by the village. This will at once a challenge for the village whether this approach can solving the problems faced by the village so far. 
The village authority was then described in the Minister of Home Affair regulation No. 44/2016 concerning Village Authority. More than that, in terms of the budget, based on Article 72 of the Law the village allows to get funds from various sources source for carrying out the authority it has. That is village original income, Indonesian Budget (APBN) allocation through government programs village based, part of the results of district tax and retribution/the municipality is a little $10 \%$, the allocation of village funds is part from the balancing funds received by the district / city at least $10 \%$ after deducting special allocation funds, financial assistance from Provincial and regency/city budget (APBD), grants and donations as well other possible funds. With the issuance of the Village Law, a shift occurred approaches from village authorities that are targeted, as well in the previous legislation, to authority mandate village. In addition, the position of the village becomes community governance which is a combination of self-governing community and local self-government based on principles recognition and subsidiarity as the main principle besides the principles others. New approaches and funds allocated to villages this will be a challenge for the village to solve various problems that have been held so far. The three main actors have important role in implementing village authority which includes Village Government (Village Head and Village Equipment), Agency Village Consultation (BPD), and village communities.

Though efforts to achieve a prosperous society require the implementation of good governance continuously that require an element of professionalism from government officials in carrying out government duties. Therefore, there needs to be a breakthrough effort that can lead villages in Indonesia to become independent villages, through increasing the capacity possessed by their apparatus. Efforts to increase the capacity of village officials are very important to do, not only related to the amount of village funds that they have to manage (an average of IDR. 1.4 billion), but also regarding the large resources (natural and human) owned by the village. That is, the village already has a lot of capital to realize the aspirations of its citizens, welfare. Starting from natural resources and human resources, to regulation through Village Law No. 6 Year 2014.

The efforts to improve the quality of village officials in Indonesia within the framework of political law, which is interpreted by Mahfud MD (2009) as a policy breakthrough to overcome problems that hinder the achievement of the objectives of its regulation. This is in line with concept of public policy that interpreted as an action taken by the government to overcome various problems (Nugroho 1, 2017). Policies are essentially decisions that directly regulate the management and distribution of natural, financial, and human resources in the public interest (Suharto, 2010). Public policy refers to a term or concept to explain certain specific action option that are very specific, such as in certain field in public facilities sectors. 
The logical explanation of the importance of improving the quality of village officials in Indonesia is related to the existence of the village itself. The village is home to the majority of Indonesia's population, as well as the location of most natural resources. That is, if natural and human resources in the village can be managed properly, then the results will improve the living standards of the Indonesian population. Therefore, the government is required to be able to find and present policies that can improve the capacity of village officials. This demand is increasingly finding its significance in the era of regional autonomy, because local governments (especially districts) can contribute greatly to increasing the capacity of village officials. Political discourse on policy has increasingly found its special place in the era of decentralization which was rolled out in post-reform Indonesia. This is of course as an implication of the submission of most of the duties and responsibilities of the central government to regional governments. According to Bird and Vaillancourt (1998) and Stoker (1991), regional autonomy was chosen as a development approach in post-New Order Indonesia because it promised to occur: economic efficiency, program cost effectiveness, accountability, increased resource mobilization, reduced disparity, increased political participation, and strengthening democracy and political stability. Through decentralization, local governments play a greater role in development because they now have the authority and responsibility to carry out community development in their jurisdiction. Because local governments are considered to have better knowledge of the needs and preferences of their citizens, the development process in the decentralization policy model should be more efficient than the centralized policy model in the framework of improving the welfare of local communities. This is because in the decentralization policy, local governments can better allocate resources to meet people's needs. Thus, theoretically, as stated earlier that the decentralization policy model should be able to bring a better level of welfare compared to a centralized (centralized) system. This is none other than because local governments that already have broad authority in regional management in the regional autonomy system are expected to produce public policies in the form of development programs.

This is in line with the findings of the data revealed from various related studies. These are some of the advantages of decentralization that lead to the establishment of a system as a method of managing government in post-reform Indonesia. Stoker and Bird and Vaillancourt's statements above are in line with the research findings conducted by Kisman and Tasar (2014), Witkowski and Kiba-Janiak (2014), HM (2017). These studies show the magnitude of the role of local governments in an effort to overcome the social problems faced by society. These studies also emphasize that local governments can better improve people's welfare, compared to when the government is still in a centralized system. In addition, studies conducted by Nak-ai etc. (2018), Sharma (2015) and Brillo (2017) also show that the role played by local governments in collaborating with several stakeholders is able to improve the lives of the people. 
Based on the second perspectives above, efforts to overcome the problem of the low quality of village apparatus in carrying out management functions can be carried out in various forms. One of them can be done by optimizing the National Framework for Developing and Enhancing Government Capacity in Order to Support Decentralization, Policy of the Minister of Home Affairs and Head of National Development Planning Agency (Bappenas) 2002. In this guide it is stated that the development and improvement of capacity includes three levels, namely: 1) System level, namely regulatory framework and policies that support or limit the achievement of certain policy objectives; 2) Institutional or entity level, namely organizational structure, decision-making processes within the organization, work procedures and mechanisms, management instruments, relationships and networks between organizations, etc .; 3) Individual level, namely the level of skill, qualification, knowledge/insight, attitude, ethics and motivation of individuals working in an organization. This effort can be done by optimizing training to increase managerial knowledge for village officials to be able to exercise governmental functionsand the appropriate legislation development bases on villageregulation (Ismiyarto and Sawitri, 2016).

According to Wahyudi's (2016) record, the optimization of the government's capacity building mechanism has proven to be able to improve the ability of village officials to carry out their functions. Village apparatuses who follow the stages of capacity building are provided with knowledge about village management, from planning, implementation to evaluation. The same thing was also expressed by Nugroho etc. (2018) who said that the participation of village officials in capacity building training enabled them to understand aspects surrounding village management, such as administration and planning and activity reports. Along with the increasingly complex problems that exist in the village, the development of the capacity of the village apparatus is certainly not just about administrative aspects. Moreover, village apparatus are required to have knowledge and capabilities of public services, asset management, finance and regulatory socialization. This is certainly related to several aspects listed in Law Number 6 of 2014 about Village as the most recent reference in village management. This means that efforts to overcome the problem of the quality of village apparatus which are still low in a legal political perspective are carried out by strengthening the training content by including material on village budget preparation, village fundsmanagement, village wealth management, and villageowned business entity (BUMDes) management.

Several regions in Indonesia have and are currently carrying out several programs aimed at increasing the capacity of village officials, one of them is The Government of West Kalimantan Province. On the basis of the desire that the village apparatus as the spearhead of development have a good ability in managing its territory, The Government of West Kalimantan Province held a series of activities funded through the Provincial Budget Number046/BPMPD/2015 August 2, 2015 (Ismiyarto and Sawitri, 2016). This 
program was attended by village heads, village secretaries and other village apparatus under the coordination of the Village Government Office (PMD) in the West Kalimantan Province. This village apparatus training program initiated by the provincial government has greatly contributed to the increased ability of the village government to manage its territory in West Kalimantan Province. This positive impact certainly occurs because of right method implementation training then the subject matter will be carriedoptimally and will be more useful against capabilities ofVillage Government apparatus. The training technique has been used participatory learning methods of training, it is expected the communications presence between the two sides and the village teachers trained. The type of this method is speech, interview, brainstorming, discussion groups, plenary discussions, panel discussions, demonstration, practicing, work individual simulation, work group, and suggestions for a jarring experience. Thistype is important because the village apparatus is the largest human and natural resource manager in Indonesia, so they are required to have good managerial skills.

Other example of the implementation of political law and policy related to village governance is carried out by The Government of Merangin Regency, Jambi Province. The effort to increase the capacity of the village apparatus is one of the priorities of The Government of MeranginRegency program, especially in the time of The Regent of $\mathrm{Al}$ Haris who is now undergoing a second period of his leadership. This can be seen in the big vision carried out by The Government of Merangin Regency, which wants the largest region in the Jambi Provision to be superior in the Agriculture and Tourism Sector. As is known that Merangin Regency is an area that has the largest rubber plantation $(132,192$ hectares) and oil palm plantation (53,792 hectares) area in Jambi Province, not to mention tourism potential, and these main natural resources are mostly owned by farmers and live in villages. Therefore, increasing the capacity of village apparatus to be something that is undoubtedly done by The Government of Merangin Regency as an effort to improve people's welfare.At first glance this vision does not correlate directly with efforts to increase the capacity of village officials reflected in the latest village regulations in Indonesia. However, if it is considered further, it can be seen that this vision will be realized if superior resources in agriculture and tourism are managed properly. Management of these agricultural and tourism resources can only be carried out by the village apparatus because their existence is in the village. Therefore, good management capability is absolutely possessed by the village apparatus so that the big vision of Merangin Regency can be realized well too.

Efforts to improve the capacity of village officials in Merangin Regency are carried out in various forms of activities, both those related to central and provincial government programs, as well as districts. The activities carried out by The Government of Merangin Regency through the Village Community Empowerment Service are a Workshop on 
Village Financial Management Systems with the SISKEUDES Application and the Provision of Village Technical Capacity Building (P2KTD). These activities were attended by all apparatus in 205 villages throughout Merangin Regency, specifically the village head and village secretary. These programs are intended to assist village officials at Merangin Regency in conducting village management, from administration to village finance at the stage of budgeting, administration, reporting, to accountability. Through apparatus that have good village management capabilities, various village resources can be used to improve the welfare of the community in Merangin Regency. These two programs have been running since 2016 and significant impacts have been felt by village officials in MeranginRegency. Although it is not yet perfect, the efforts made by the regional government deserve to be appreciated as a form of concern for increasing the capacity of the village apparatus that manages so much village resources.

\section{CONCLUSIONS}

Effort to overcome the problem of limited human resources in the village to achieve the objectives of village regulation as contained in Village Law Number 6 Year 2014 can done by implementation of political law and public policy concept. Political law is not as understood so far as the formation of law through legislation, but strengthening the capacity and quality of law enforcement and the means of law enforcement and the development of legal culture are also part of it and public policy is an action taken by the government to overcome various problems. Based on thesetwo perspectives, efforts to overcome village problems can be done by increasing the capacity of village officials. The government, especially the regional government, is required to present programs aimed at increasing the knowledge of village officials. After the ability of village officials to increase, the management of village resources can be done well so as to create independent villages with prosperous residents.

\section{REFERENCES}

Anto, Rola Pola. Amir, Muhammad (2017). 'Competence of village apparatus in management of village funds in North Konawe Regency- Indonesia'. IOSR Journal of Business and Management (IOSR-JBM), Volume 19, Issue 11. Ver. VII (November. 2017), p. 66-71. DOI: 10.9790/487X-1911076671

Asrori (2014).'Kapasitas perangkat desa dalam penyelenggaraan pemerintahan desa di Kabupaten Kudus (Capacity of Village Devices in Organizing Village Government in Kudus District)' Jurnal Bina Praja, Vol. 6 No. 2, June 2014, p. 101-116.

Badan Pusat Statistik [Indonesian Central Bureau of Statistics] (2018). Indonesia dalam angka 2018/ Indonesia in figure 2018. 
Badan Pusat Statistik [Indonesian Central Bureau of Statistics] (2018). Indeks pembangunan desa 2018/ Village development index 2018.

Bird, R., Vaillancourt, F. (1998). Fiscal decentralization in developing countries.United Kingdom: Cambridge University Press.

Brezovšek, M. (2014). Local self-government in Slovenia : theoritical and historical aspect. Ljubljana: Faculty of Social Sciences,University of Ljubljana.

Brillo, Bing Baltazar C. (2017). The politics of lake governance: Sampaloc Lake, Pandin Lake, and Tadlac Lake of the Laguna de Bay Region, Philippines. Asia-Pacific Social Science Review (2017) 17(1): 66-79.

Dye, Thomas R. (1991). Understanding public policy. England: Prentice-Hall, Inc.

Fadli, Muhammad etc. (2011). Pembentukan peraturan desa partisipatif (Establishment of participatory village regulations). Malang: Universitas Brawijaya Press.

Hartono, CFG Sunaryati (1991). Politik hukum menuju satu sistem hukum nasional (Political law toward one national law system). Bandung: Penerbit Alumni.

HM, Pahrudin (2017). 'The study of government's role for welfaring rubber farmer in the globalization vortex'. JSP: Jurnal Ilmu Sosial dan Ilmu Politik, Vol. 21, Issue 2, November 2017. https:// doi.org/10.22146/jsp.30436

Huda, Ni'matul (2015). Hukum pemerintahan desa: dalam konstitusi Indonesia sejak kemerdekaan hingga era reformasi (Village government law: in the Indonesian constitution since independence until the reformation era). Malang: Setara Press.

Ismiyarto. Sawitri, Sri (2016). 'Study of implementation village apparatus training in West Kalimantan Province'. Proceeding on Innovation in Regional Public Service for Sustainability (ICPM 2016), Atlantis Press.

Kisman, Zulfukar Aytac and Tasar, Izzet (2014). 'The key element of local development' Procedia Economics and Finance, 15, 1689-1696, 2014. https://doi.org/10.1016/S22125671(14)00642-X

Mahfud MD, Moh. (2006). Membangun politik hukum, menegakkan konstitusi (Building a political law, upholding the constitution).Jakarta: Pustaka LP3ES Indonesia.

Marvasti, Amir B. (2004).Qualitative research in sociology. London: SAGE Publications.

Maschab, Mashuri(2013). Politik pemerintahan desa di Indonesia (Politics of village in Indonesia). Yogyakarta: Penerbit PolGov.

Miles, Matthew B. and A. Michael Huberman (1992). Analisis data kualitatif (Qualitative data analysis), Translated by: Tjetjep Rohendi Rohidi. Jakarta: Universitas Indonesia Press.

Nak-ai, Worayuth etc. (2018). 'Community public policy process for solving cadmium contamination problems in the environment: a case study of Mae Sod District, Tak Province. Kasetsart Journal of Social Sciences 39 (2018) 59-66. https:// doi.org/10.1016/ j.kjss.2017.11.006 
Nonet, Philippe and Selznick, Philip(1978). Law and society in transition: toward responsive law. England: Harper and Row.

Nugroho, Riant. (2018). Public policy. Jakarta: PT. Elex Media Komputindo.

Nugroho, Setyo etc. (2018). ‘Pengembangan kapasitas aparatur pemerintah desa dalam upaya mewujudkan good governance (Capacity development of village government apparatus in efforts to realize good governance)' Jurnal Administrasi Publik (JAP), Vol. 1, No. 5, p. 1010-1015.

Rosadi, Otong dan Desmon, Andi (2012). Studi politik hukum: suatu optik ilmu hukum (The study of political law: an optical law). Yogyakarta: Thafa Media.

Sahi, Nirmala A. (2018). 'Peningkatan kualitas perangkat desa guna pemantapan pelaksanaan pembangunan di Gorontalo (Quality improvement of village devices to strengthen development implementation in Gorontalo)' Gorontalo Journal of Public Administration Studies, Vol. 1, No. 1, April 2018. DOI: https://doi.org/10.32662/ gjpads.v1i1

Sharma, Chanchal Kumar (2015). Reimagining federalism in india: exploring the frontiers of collaborative federal architecture. Asia-Pacific Social Science Review 15 (1) 2015, p. $1-25$.

Stoker, Gerry (1991). The politics of local government. London: The Macmillan Press Ltd.

Suharto, Edi (2010). Membangun masyarakat memberdayakan rakyat (Developing community and empowering people). Bandung: PT. Refika Aditama.

Suwardjo, H. W. (2009). 'Penguatan pemerintahan desa: pengalaman empirik kepemimpinan desa' (Strengthening village governance: an empirical experience of village leadership). In Pengembangan kapasitas pemerintah desa dan pengembangan pelayanan di tingkat desa (Development of village government capacity and service development at the village level). Samarinda: PKP2A III LAN, p. 55-63.

Syaifullah, Muhammad (2017). 'Understanding of village apparatus on implementation accounting villages'. International Journal of Science and Research (IJSR), Volume 6 Issue 8, August 2017. DOI: 10.21275/ART20176211

Wahyudi, Andi Etc. (2016). Peningkatan kapasitas desa (Improving capacity of village). Samarinda: PKP2A III LAN.

Wikowski, Jaroslaw and Kiba-Janiak, Maja (2014). 'The role of local governments inthe development city logistics' Procedia-Social and Behavioral Sciences, 125, p. 373-385,2014. 